\title{
Territory in the Constitutional Standards of Federal States
}

\author{
Lyudmila But'ko ${ }^{1}$, Marina V. Markhgeym ${ }^{1}$, Aleksej N. Nifanov ${ }^{1}$, Alevtina E. Novikova ${ }^{1} \&$ Sergej A. Usatov $^{1}$ \\ ${ }^{1}$ Belgorod State University, 85 Pobedy Street, Belgorod, The Belgorod Region, Russia \\ Correspondence: Lyudmila But'ko, Belgorod State University, 85 Pobedy Street, Belgorod, The Belgorod Region, \\ 308015, Russia. E-mail: russia@prescopus.com
}

Received: June 19, 2017

doi:10.5539/jpl.v10n4p216
Accepted: July 18, 2017 Online Published: August 30, 2017

URL: https://doi.org/10.5539/jpl.v10n4p216

\begin{abstract}
In this article, general and specific approaches to the consolidation of provisions on the territories within the state have been identified, on the basis of textual analysis of the federal states' constitutions. The characteristic of the relevant constitutional norms is given. Taking into account constitutional specificity of listing the types of the state territories, classical and variational models were proposed in this article; the constitutions of federal states, distinguished by their originality in the studied group of legal relations, were defined.
\end{abstract}

Keywords: territory, state territory, federation, territory of the federation subjects, state, land, municipal territory

\section{Introduction}

The territory, being an integral feature of the state, is at the center of scientific interest constantly (Elden, 2007; Mellor, 1989; Mulkay et al., 1975; Smith, 1936; Herb \& Kaplan, 1999), in particular, within the framework of jurisprudence (Anderson, 1997; Baburin, 2005; Nifanoy; 2011).

The objective rates of the world state-building processes, as well as geopolitical challenges, require a serious conceptual study and legislative regulation of the territorial status on its basis. In this regard, the foreign experience of the constitutional consolidation of provisions on the territories in federal states, is of particular interest (in view of the commonality of the territorial structure with Russia).

Taking this into account, the article focuses on nine federations from different continents (Austria, Belgium, Germany, the USA, Brazil, Argentina, Mexico, India, and the United Arab Emirates). Such selection is due to the existent models of constituting federal relations, recognized as original: Austrian, Belgian and American.

\section{Methodology}

Various general scientific methods and means of logical cognition are used in the work: system, analysis and synthesis, abstraction and formal logical approach. The use of lingo-legal, historical, comparative-legal methods, as well as the methods of content analysis, facilitated the disclosure of the topic.

\section{Discussion and Results}

Carried out analysis of declared texts of the federal states' constitutions allowed to establish, that state territories were named in various terms there: "territory of the federation" (Austria); "national territory", "Argentine territory" (Argentina); "state territory" (Mexico) (Http://worldconstitutions.ru/?cat=8).

Further considerations of the constitutive acts of the federal states, for the purpose of revealing in them the norms of the territory, gave the authors some grounds for defining three groups.

The first group includes the constitutions of states, where the status characteristics of the state territories are specified in detail (Belgium, India, Mexico). The constitutions of these countries have specialized sections for the stated questions.

For example, the constitution of Belgium has the chapter "on the Belgian federation, its parts and territory" (Http://worldconstitutions.ru/?cat=8). It is determined, that the constitution of Belgium uses an original approach to the enumeration of the constituent parts of the state and, accordingly, the territories of the state.

Taking into account an integrated approach to the definition of territory, by interpreting article 1 of the Belgian constitution, it is concluded, that the territory of the state of Belgium consists of the territory of communities and regions. At the same time, Belgium includes three communities: the French community, the Flemish and the German-speaking (article 2); three regions, consisting of the provinces: Walloon region (provinces - Walloon 
vrabant, Hainaut, liege, Luxembourg and Namur), Flemish region (provinces - Antwerp, Flemish Brabant, west Flemish, east Flemish and Limburg) and Brussels region (article 3).

Also, Belgium consists of four linguistic regions: the French language region, the Dutch language region, the bilingual region of Brussels-the capital and the region of the German language. Thus, based on the linguistic criterion, it is possible to distinguish four corresponding territories in Belgium.

Each commune of the kingdom is the part of one linguistic region.

Consequently, it is logical to make the conclusion about the existence of provinces and commune territories, which are contextually indicated in the process of definition of larger territorial entities.

The constitution of India also has a separate chapter with the title "the union and its territory" (Http://worldconstitutions.ru/?cat=8). In addition, the constitution of India has a significant number of appendices; the first of ten appendices should be noted. It contains a list of states with an indication of their territorial boundaries and a list of union territories.

The question about the form of territorial organization in India was always extremely important, due to the existence in the country more than a dozen nations, many nationalities and tribes. In its development, the Indian federation has gradually evolved. Initially, the constitution provided for the inclusion in the federation of three groups of states - "a", "b" and "c", as well as the territories mentioned under the letter "d". This territorial structure became the basis, with the help of which, the reorganization of the states, according to the linguistic principles, was subsequently carried out and several Hindi-speaking states were created (Uttar-Pradesh, Madhya-Pradesh, and Bihar) (Http://worldconstitutions.ru/?cat=8).

Article 1, paragraph 3 of the constitution of India stipulates, that the territory of India includes: the territories of the states, specified in the first appendix, as well as other territories, that can be acquired.

In this way, the Constitution of India is distinguished by the detailed regulation of the state territories. It contains separate sections for the United States (chapter VI), the union territories (chapter VIII), Panchayats (chapter IX) and municipalities (chapter IXA). The territories of the panchayat and the municipality are the territories of the local self-government institutions. From the content of the Constitution of India, we can also conclude that there are such territories in the state as: a district ("means a district within the territory of the certain state" - article 243 ); the territory of the village (article 243).

In each state, Panchayats can be formed in the village, intermediate level (meaning the level between the village and the district, indicated by the governor of a certain state in the public notice) and at the district level (part 1 of article 243b).

Further analysis of the constitution of India has also shown the existence of the central and municipal zones.

Article 243q provides for the procedure of municipalities' formation, hence, the rules for the separation of the municipality's territory, as well as the territory of the intermediate zone, the small urban zone and the large urban zone. They are separated taking into account the population of the zone, its density, the total revenues of the local administration, the percentage of employment in non-agricultural types of activity, economic importance or other factors.

Thus, in India, at the constitutional level, besides the classical state territories (federal significance, subjects of the Federation, institutions of local self-government) there are other territories, corresponding to additional criteria (for example, the intermediate zone, small and large urban areas).

The Constitution of the Mexican United States has a special chapter ii "on the constituent parts of the federation and on the state territory". In accordance with article 42, the state territory includes constituent parts of the federation and adjacent islands, located in both seas. It also includes the island of Guadeloupe and the Revillagigedo Islands, located in the Pacific ocean.

Also, article 43 lists the constituent parts of the federation, which are the states.

Based on article 115 of the United Mexican States Constitution, it can be concluded, that there are territories of the states and municipalities.

The second group includes the constitutions of states, which norms on the state territories are not consolidated in a separate independent section. However, these norms are sufficiently detailed.

Thus, the Constitution of Austria states, that the territory of the Federation includes the territories of the lands (part 1 of article 3). The lands of Austria are listed in part 2 of article 2. All lands are "independent", but as for their constitutional power and their practical importance in public administration, their autonomy is very limited 
(article 2).

Despite the centralized nature of the Austrian federation, the constitution guarantees the territorial inviolability for its subjects. According to article 3 of the constitution, the change of federal territory, which is, at the same time, the change of one of the lands territories, as well as it is the border changes of one of the lands within the territory of the federation, can be made, only on the basis of identical constitutional laws of the federation and the land concerned, besides the cases of concluding peace treaties.

Article 115 of the Austrian constitution contains detailed provisions on communities: each land is divided into communities. The community - is a territorial unit, with the right of self-government and, at the same time, an administrative unit. Every part of the territory must belong to a community. In total, there are almost 2360 communities in Austria (in the middle of the last century, the number of communities reached four thousand).

In addition to these territories, taking into account the criteria for the extension of the jurisdiction of specially designated structures, it is possible to single out the territories of the Austrian union of communities and the Austrian union of cities (these unions are made for representing the interests of the communities).

Thus, there is an indication of the existence "classical" territories within the state: federal (state), subjects of the federation and municipal (administrative).

The constitution of the united states of Brazil also does not provide for a separate section, regulating the status of territories in the state $(\mathrm{Http}: / /$ worldconstitutions.ru/?cat $=8)$. However, its certain provisions are sufficiently detailed in the following field. So, in reliance on the interpretation of article 1 of the united states of Brazil constitution, we can conclude, that the territory of the union, the federal district and the territory, are constitutionally determined. At the same time, the territory of the union capital is the territory of the federal district.

The provisions of the united states of Brazil constitution, which clarify the structure of the territory in the state on the basis of ownership, are of particular interest. Thus, article 34 of the constitution States, that the ownership of the union includes:

- Lakes and all waterways in the territory, to which its authority extends or which covered the territory of more than one state, served as a border with other countries or extended on foreign territory, as well as islands of rivers and lakes, located in the border zones;

- The part of uncultivated lands, needed to protect borders, fortifications, military installations and railways.

It is also said, that the property of states includes lakes and rivers, located within the territory, to which its authority is extended, as well as the sources or estuaries of rivers, located on the territory of the state (article 35).

The fact of placing norms on the territory in the transitional constitutional provisions is distinctive.

The third group contains the constitutions, which fragmentarily consolidate the provisions on the state territories (Argentina, Germany and the United Arab Emirates).

Thus, the constitution of Argentina does not contain norms, determining the status of the federal territory, its subjects, the municipal territory in the state, etc. The conclusion, that the territory of Argentina consists of the territories of its provinces, can be done only on the basis of the interpretation of the constitution preamble: "we, the representatives of the people of the Argentine nation, gathered in general constituent assembly by the will and election of the provinces which compose it, in fulfillment of pre-existing pacts, in order to form a national union...".

Further, the paragraph 14 of article 67 to the competence of the assembly includes the final establishment of the border of the national territory, the determination of the provincial territory limits, the creation of new provinces and the establishment by special legislation of the organization system of administration and management for the national territory, remaining outside the borders, established in the provinces.

Thus, based on the aggregate interpretation of these norms, it was made the conclusion, about the existence of provincial territories in a given state.

In the constitution of the federal republic of Germany there are no especially dedicated sections for the territorial structure (Http://worldconstitutions.ru/?cat=8). The conclusion about the existence of territories in the state follows from the text of the constitution preamble: " the Germans in the states [Länder] of Baden-Wurttemberg, Bavaria, Berlin, Brandenburg, Bremen, Hamburg, Hesse, lower Saxony, Mecklenburg-western Pomerania, north Rhine-Westphalia, Rhineland-Palatinate, Saarland, Saxony, Saxony-Anhalt, Schleswig-Holstein and Thuringia have achieved the unity and freedom of Germany in free self-determination"; as well as from part 1 of article 20: 
"the federal republic of Germany is a democratic and social federal state". In such a way, the territories of the federation, as well as the territories of the lands, are legalized.

Article 1 of the constitution of the United Arab Emirates says that the uae is unified independent sovereign state. This country consists of the following emirates: Abu Dhabi, Dubai, Sharjah, Ajman, umm Kaiwain and Fujairah (Http://worldconstitutions.ru/?cat=8). Any independent Arab state can join the United Arab Emirates with the consent of all members of the supreme council. Thus, the constitution defines the status of the state territory and the territories of emirates.

Also, we should note, that in the constitution of the united states of 1787 , there is no special section and no certain norms, regulating the status of the territory (Maklakov, 2003).

We should also pay attention to the specifics of detalization in the constitutions of the studied states. Thus, an exhaustive list of constituent parts of federations is presented in the text of constitution (Austria, Mexico, the United Arab Emirates); its preamble (Germany), annexes to the constitution (India); in transitional constitutional provisions (on the procedure for the formation of representative bodies - in brazil). In the constitutions of the USA and Argentina such list is fully absent.

\section{Conclusions}

The experience of consolidating the status of territories in federal states, pointed to a different degree of detailing the relevant provisions in the constituent instruments: the existence of the separate section, devoted to the federation and its territory (Belgium, India, Mexico), detailed description of studied features of state territories in various norms (Austria, Brazil), fragmentary consolidation (Argentina, Germany, the United Arab Emirates).

In the course of the study, special features were also established in the constitutional listing of the types of state territories. It was identified "classical" model, which considered the separation of the federal territory, its subjects (the territory of local self-government institutions) - Argentina, Belgium, Brazil, Germany, the United Arab Emirates. Along with this model, a variant model was also identified, which, in addition to the "classical" types of territories, introduced additional varieties of territories (Austria, India, Mexico), based on various criteria.

The constitutions of the federal states, distinguished by their originality in the studied group of legal relations, were singled out:

- Belgium (in terms of criteria for dividing the territory of the state);

- India (in terms of the most complete legal regulation of various types of territories in the state);

- The USA (regarding the absence of norms for territories regulation).

\section{References}

Anderson, M. (1997). Frontiers: territory and state formation in the modern world. Cambridge: polity press, 272 p.

Baburin, S. N. (2005). The world of the empire: the territory of the state and the world order. Moscow: the legal center, 770 pp. (in Russian).

Elden, S. (2007). Governmentality, calculation, territory. environment and planning d: society and space. Vol. 25. Issue 3. Pp. 562-580.

Herb, G. H., \& Kaplan, D. H. (1999). Nested identities: nationalism, territory, and scale / ed.. Lanhan, Newyork, oxford: rowman \& littlefield, $343 \mathrm{p}$.

Maklakov, M. (2003). Constitutions of foreign states/ ed.: volters kluver, 564 p. (in Russian).

Mellor, R. E. H. (1989). Nation, state and territory: political geography. London; Newyork: routledge, 217 p.

Mulkay, M. J., Gilbert, G. N., \& Woolgar, S. (1975). Problem areas and research networks in science. Sociology, 9(2), 187-203. https://doi.org/10.1177/003803857500900201

Nifanov, A. N. Territory: constitutional legal phenomenology of the state attribute: monograph. Rostov-on-don: rostizdat, 266 p. (in Russian).

Smith, A. D. (1936). States and homelands: the social and geopolitical implications of national territory. $\begin{array}{llll}\text { millennium: } \quad \text { journal of international } & \text { studies, } & 10(3), & \text { 187-202. }\end{array}$ https://doi.org/10.1177/03058298810100030201 


\section{Copyrights}

Copyright for this article is retained by the author(s), with first publication rights granted to the journal.

This is an open-access article distributed under the terms and conditions of the Creative Commons Attribution license (http://creativecommons.org/licenses/by/4.0/). 